\title{
The antifungal effect of the biopreparation of Xenorhabdus budapestensis bacteria on some Candida species
}

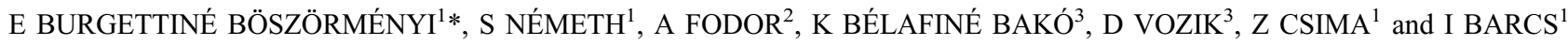 \\ ${ }^{1}$ Faculty of Health Sciences, Department of Epidemiology, Institute for Health Promotion and Clinical Methodology, \\ Semmelweis University, Budapest, Hungary \\ ${ }^{2}$ Department of Genetics, University of Szeged, Szeged, Hungary \\ ${ }^{3}$ Research Institute of Bioengineering, Membrane Technology and Energetics, University of Pannonia, Veszprém, Hungary
}

(Received: March 12, 2018; revised manuscript received: May 14, 2018; accepted: August 22, 2018)

\begin{abstract}
Introduction: The prevalence of invasive fungal diseases shows an increasing trend. Due to the frequent but unprofessional usage of antifungal medications, the fungi show decreasing susceptibility towards these agents and this trend may lead to the emergence of resistant pathogens. There is a great need to develop antifungal medications with new mechanisms. One of these options is to apply proteins with natural antifungal effects. The objective was to measure the antifungal efficacy of Xenorhabdus budapestensis in vitro on clinical Candida species (Candida albicans, Candida lusitaniae, Candida krusei, Candida kefyr, Candida tropicalis, and Candida glabrata). Materials and methods: We defined the sensitivity of the Candida species towards antibiotics. We conducted agar diffusion tests with the cleaned biopreparation of $X$. budapestensis $(100 \%)$ and its dilutions $(80 \%, 60 \%, 40 \%$, and 20\%). Zones of inhibition were measured after 24, 48, and $96 \mathrm{hr}$. Results: Most of the tested Candida species have shown sensitivity to the biopreparation and its $40 \%$ dilution. The area of the zones of inhibition did not decrease after several days. The most sensitive species was $C$. lusitaniae and the least sensitive was $C$. krusei. Conclusion: We assume that the proteins produced by $X$. budapestensis have antifungal effect, as the area of the zones of inhibition did not change.
\end{abstract}

Keywords: Candida species, antifungal effect, Xenorhabdus budapestensis, resistance

\section{INTRODUCTION}

The number of diseases caused by fungi is gradually increasing. The most common species is Candida albicans, the other group consists of non-albicans Candida species as per its frequency [1].

C. albicans is part of the normal human microflora, but under certain circumstances, it may cause superficial or invasive fungal diseases. It may produce a biofilm on a biotic or abiotic surface and its adhesion is supported by adhesins [2]. Its hyphae may produce certain hydrolases, which promote their entry to the host cell. They are also capable of easily adapting to various $\mathrm{pH}$ levels and other stress factors within the human body [3].

Candida glabrata is the second most common species, it has been isolated from human faeces in 1917 [4]. Its growth temperature optimum is $37^{\circ} \mathrm{C}$, which is the core temperature of the healthy human body. Its tolerance towards different stress factors is very high and tolerates the absence of nutrients well. It is also resistant against the attacks of the immune system. It has shown high resistance against azoletype antifungal medications. A protein called adhesin ensures its adhesion to the cell membrane. It easily produces biofilm on medical devices, such as catheters [5].
Candida lusitaniae occurs more rarely than the rest of the Candida species. The first reports of this species were presented in 1979. Its teleomorph form is called Clavispora lusitaniae. It is resistant to Amphotericin B and produces haemolysin [6]. The sensitivity towards Amphotericin B can be increased if combined with fluconazole and 5-fluorocytosine [7]. One of the reasons behind the resistance is the change in the biosynthesis of ergosterol. Due to that, the ergosterol content of the cell membrane decreases [8].

Candida kefyr has been isolated from kefir in 1909, its former name is Candida pseudotropicalis. Its teleomorph form is the yeast of kefir, the Kluyveromyces marxianus [9]. Rarely, it may cause invasive infections, especially simultaneously with malignant diseases of the haematopoietic system [10]. It produces protease, haemolysin, and phospholipase [6].

The prevalence of Candida krusei is increasing similar to C. glabrata. It is fluconazole resistant due to the altered

\footnotetext{
* Corresponding author: Erzsébet Burgettiné Böszörményi; Faculty of Health Sciences, Department of Epidemiology, Institute for Health Promotion and Clinical Methodology, Semmelweis University, Vas utca 17, Budapest H-1088, Hungary; E-mail: boszormenyie@se-etk.hu
}

This is an open-access article distributed under the terms of the Creative Commons Attribution-NonCommercial 4.0 International License, which permits unrestricted use, distribution, and reproduction in any medium for non-commercial purposes, provided the original author and source are credited, a link to the CC License is provided, and changes - if any - are indicated. 
functioning of the P450 isoenzyme [11]. It also shows decreased resistance to Amphotericin B and flucytosine. It is likely to produce biofilm [12] and to produce phospholipase [6].

Candida tropicalis was first reported as Oidium tropicale in 1910. It is a frequently isolated Candida species especially in cancer patients. It has a strong adhesive feature and easily produces biofilm [6]. Its prevalence is greatly increased due to the use of broad-spectrum antibiotics or long-lasting catheters. The matrix of the biofilm differs from the ones produced by other species due to its hexosamine content. It is resistant to Amphotericin B and fluconazole. Its hyphaproducing ability and enzyme production (phospholipase, protease, and haemolysin) only increase its virulence [6].

The number of C. krusei, C. glabrata, and C. tropicalis infections also increases gradually.

\section{OBJECTIVES AND METHODOLOGY}

The objective of our work is to test the antimicrobial effects of the protein produced by the Gram-negative insect pathogen bacteria Xenorhabdus budapestensis on six Candida species (C. albicans, C. krusei, C. tropicalis, C. lusitaniae, $C$. kefyr, and C. glabrata). The isolated specimens are from clinical samples.

Our experiment has been motivated by two factors. One of them is the results originating from the previous testing of the cell-free culture media (CFCM) and its cleared biopreparation [purified fraction (PF)] of $X$. budapestensis on Gram-negative and Gram-positive bacteria originating from veterinary and human infections [13-16].

The other factor is the experiments conducted with Xenorhabdus cabanillasii bacteria. This bacterium was able to inhibit the growth of various filamentous fungus species, including Fusarium oxysporum and Candida as well [17]. It has to be noted that our team has also conducted experiments with filamentous fungi (Aspergillus fumigatus, Aspergullus flavus, and Fuzarium spp.). However, with the clinical samples, we have not been able to achieve any antifungal effects that could be considered as lasting. These experiments prove that there are major differences between the antimicrobial proteins of the various Xenorhabdus species.

The antimicrobial agent of $X$. budapestensis is a hexapeptide protein, which was named as bicornutin- $A$ back in 2009 [18]. Researchers in Frankfurt also noted the antimicrobial effects of $X$. budapestensis. MALDI spectrometry has proven that this hybrid molecule protein is rich in arginine and contains putrescine and phenylethylamin, and was named as fabclavin. Moreover, a 6,848-bp section of the bicA gene has been discovered, which is responsible for the production of bicornutin-A. The gene cluster has been recognised in E.coli DH1OB bacteria with the heterologous expression of the bicA gene [19].

Our work was carried out in the microbiology laboratory of the Faculty of Health Sciences of Semmelweis University cooperating with the Research Institute of Bioengineering, Membrane Technology and Energetics of the University of Pannonia. We have received the tested Candida species from the clinical microbiology laboratory of Semmelweis University.

\section{The process of producing CFCM}

The CFCM and the cleaned biopreparation were made from the Xenorhabdus antimicrobial peptide (XAMP)-producing primer variant of the DSM- $16342^{\mathrm{T}}$ entomopathogenic bacteria strain of $X$. budapestensis, which was able to produce the substance with the highest antimicrobial effect in previous studies [20].

The bacterium, which produces the antimicrobial substance, was grown in lysogeny broth at $25^{\circ} \mathrm{C}$ temperature, shaken at $200 \mathrm{rpm}$ and at increasing levels in three steps. After reaching the stationary phase, we have centrifuged the cell culture $\left(15,000 \times g, 20^{\circ} \mathrm{C}, 20 \mathrm{~min}\right)$ and filtered it with a $0.22-\mu \mathrm{m}$ pore-diameter (Merck Millipore, Merck Kft., An affliate of Merck KGaA, Darmstadt, Germany) filter. The CFCM was produced from this. A further $3 \mathrm{~L}$ of conditioned CFCM were cleaned, from which the fraction rich in cleaned peptides (PF) was prepared.

The prepared solutions were shaken for $48 \mathrm{hr}$ on $150 \mathrm{rpm}$ with $20 \mathrm{~g} / \mathrm{L}$ Amberlite ${ }^{\circledR}$ XAD $1180^{\mathrm{R}}$ cation ion-exchange resin - previously activated in distilled water $\left(121^{\circ} \mathrm{C}\right.$, $30 \mathrm{~min}$ ) with an autoclave - in order to better adsorb the bioactive substances. Then, the washing of the resin and extraction was carried out in multiple steps with applying methanol solutions of different concentrations in the following order: $1 \mathrm{~L}$ sterile distilled water, $500 \mathrm{ml}$ of $25 \%$ $\mathrm{MeOH}, 3 \times 300 \mathrm{ml}$ of $50 \% \mathrm{MeOH}, 3 \times 300 \mathrm{ml}$ of $80 \%$ $\mathrm{MeOH}$, and finally $300 \mathrm{ml} \mathrm{cc} \mathrm{MeOH}$, which has been acidised with $3 \mathrm{ml} 2 \mathrm{~N} \mathrm{HCl}$. The concentrated, acidic methanol fraction, which contains the components with antimicrobial effect, has been vaporised to an approximate volume of $50 \mathrm{ml}$ with the help of rotational vacuum distillation on $35^{\circ} \mathrm{C}$, then it was neutralised to $\mathrm{pH} 6$ with a $2 \mathrm{~N} \mathrm{NH}_{4} \mathrm{OH}$ solution. Then, the neutralised sample has been completely dried out. That is how the process ended with a substance with $47.7 \mathrm{mg} / \mathrm{ml}$ dry material content, which was stored in $10 \mathrm{ml}$ distilled water in a sterile tube in a refrigerator until its application.

Testing of the bioprepatation was conducted on six clinical samples of Candida species (C. albicans, C. krusei, C. tropicalis, C. lusitaniae, C.kefyr, and C. glabrata). We have transferred one unit from each pure culture of the yeast per species with a sterile inoculation loop to $10 \mathrm{ml}$ Sabouraud-dextrose culture medium, which has been cultured in a thermostat at $28^{\circ} \mathrm{C}$ under aerobic conditions after vortexing. The yeast cultures picked for testing were set to 0.5 McFarland standard on the following day.

We have transferred $300 \mu \mathrm{l}$ of each of these cultures and mixed them with $2.7 \mathrm{ml}$ of soft agar, which has been previously heated up to $54^{\circ} \mathrm{C}$, then poured them to the agar plates with a quick movement. After a 20-min wait, the soft agar settled and holes were made with a 9-mm pin drill, which were capable of holding substances up to $100 \mu 1$ [21]. Each plate contained five holes (Figure 1).

The stock solution was available in $10 \mathrm{ml}$ volumes ( $0.47 \mathrm{mg}$ dissolved in $10 \mathrm{ml}$ distilled water), which was our $100 \%$ solution. The distilled water made $80 \%, 60 \%$, $40 \%$, and $20 \%$ dilutions. The dilutions have been performed according to the macro dilution methods published by the Clinical and Laboratory Standard Institute [22]. The diluted solutions had the following dry material 


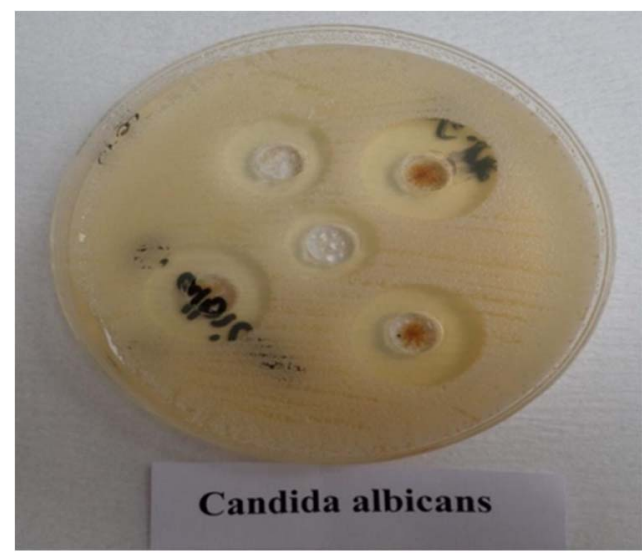

Figure 1. Agar diffusion technique on Sabouraud agar

contents: $100 \%(0.47), 80 \%(0.38), 60 \%(0.28), 40 \%(0.19)$, and $20 \%(0.095) \mu \mathrm{g} / \mathrm{ml}$. Three parallel series were made.

The sensitivity of tested Candida species to certain antifungal medications has been determined by paper disk diffusion method on Mueller-Hinton agar fungi (MHF) (Figure 2; Table 1). Based on the area of zones of inhibition, we may differentiate susceptible (S), intermediate (I), and

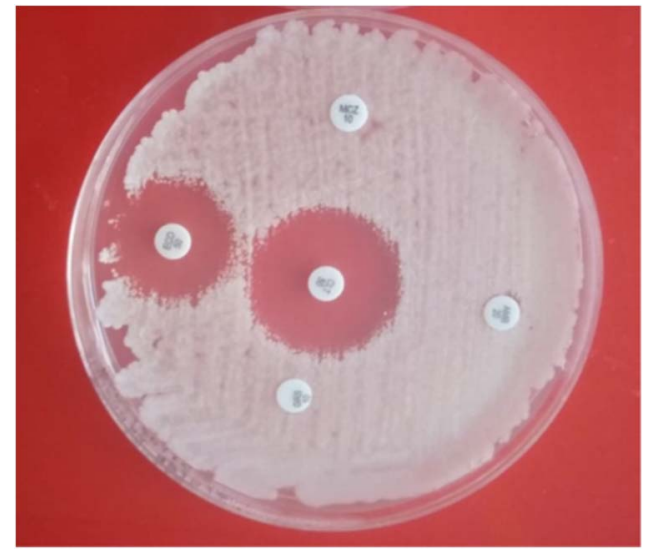

Figure 2. Determining the antifungal sensitivity of $C$. krusei with paper disk method resistant ( $\mathrm{R})$ species. A certain yeast species can be considered susceptible, if the inhibition zone is $\geq 20 \mathrm{~mm}$ (or $\geq 10 \mathrm{~mm}$ in case of griseofulvin); intermediate, if the inhibition zone is between 12 and $19 \mathrm{~mm}$; and resistant, if the inhibition zone is $\leq 11 \mathrm{~mm}$ in vitro [23].

Data analysis was carried out with IBM SPSS Statistics 20.0 software [IBM Corp. Released 2011, Armonk, NY; descriptive statistics, one-way analysis of variance (ANOVA)].

\section{RESULTS}

The first evaluation of the plates was performed after $24 \mathrm{hr}$ and the zones of inhibition were also measured (Figure 3 ). The plates were put in a thermostat for further incubation and the measurements were carried out again after 48 and $96 \mathrm{hr}$ (Figures 4 and 5).

The vertical axis displays the area of the zones of inhibition in millimeters, whereas the horizontal axis displays the tested Candida species. The columns with different colors represent different dilutions. Certain fungi species displayed a minor increase in the average area of the zones of inhibition compared to the $24-\mathrm{hr}$ values. However, the diameter of the zones remained the same at later tests.

The 96-hr average values of the three parallel zones of inhibition can be seen in Figure 5. A minor increase in the diameter can be observed with certain dilutions, but a decrease could never be observed, not even after $96 \mathrm{hr}$.

\section{DISCUSSION}

We tested the efficiency of the antimicrobial proteins synthesised by $X$. budapestensis on six different Candida species isolated from clinical samples with agar diffusion method. We have worked with five different dilutions of the cleaned, protein-rich biopreparation. Based on the results of the zones of inhibition after a 24-hr incubation period, it can be observed that the tested protein had an immediate antifungal effect on the Candida species. Every tested Candida species showed sensitivity to the $100 \%$ dilution,

Table 1. The sensitivity of Candida species for antifungal medications with paper disk method

\begin{tabular}{lcccccc}
\hline Tested active agents & C. albicans & C. glabrata & C. lusitaniae & C. kefyr & C. tropicalis & C. krusei \\
\hline Origin of yeast from human culture & Haemo-culture & Cannula & Sputum & Sputum & Wound exudate & Trachea \\
ECO $(10 \mu \mathrm{g})$ & $\mathrm{S}$ & $\mathrm{S}$ & $\mathrm{S}$ & $\mathrm{S}$ & $\mathrm{I}$ & $\mathrm{I}$ \\
ITC $(50 \mu \mathrm{g})$ & $\mathrm{R}$ & $\mathrm{R}$ & $\mathrm{R}$ & $\mathrm{I}$ & $\mathrm{R}$ & $\mathrm{R}$ \\
FC $(1 \mu \mathrm{g})$ & $\mathrm{R}$ & $\mathrm{I}$ & $\mathrm{R}$ & $\mathrm{I}$ & $\mathrm{R}$ & $\mathrm{R}$ \\
FLU $(100 \mu \mathrm{g})$ & $\mathrm{R}$ & $\mathrm{R}$ & $\mathrm{S}$ & $\mathrm{I}$ & $\mathrm{R}$ & $\mathrm{I}$ \\
KTC $(10 \mu \mathrm{g})$ & $\mathrm{I}$ & $\mathrm{R}$ & $\mathrm{R}$ & $\mathrm{I}$ & $\mathrm{S}$ & $\mathrm{S}$ \\
GRS $(10 \mu \mathrm{g})$ & $\mathrm{R}$ & $\mathrm{R}$ & $\mathrm{R}$ & $\mathrm{R}$ & $\mathrm{R}$ & $\mathrm{R}$ \\
AMB $(20 \mathrm{ut})$ & $\mathrm{R}$ & $\mathrm{I}$ & $\mathrm{R}$ & $\mathrm{S}$ & $\mathrm{R}$ & $\mathrm{R}$ \\
CLT $(50 \mu \mathrm{g})$ & $\mathrm{S}$ & $\mathrm{S}$ & $\mathrm{S}$ & $\mathrm{S}$ & $\mathrm{I}$ & $\mathrm{S}$ \\
ECO $(50 \mu \mathrm{g})$ & $\mathrm{S}$ & $\mathrm{S}$ & $\mathrm{S}$ & $\mathrm{S}$ & $\mathrm{S}$ & $\mathrm{I}$ \\
MCZ $(10 \mu \mathrm{g})$ & $\mathrm{R}$ & $\mathrm{R}$ & $\mathrm{R}$ & $\mathrm{R}$ & $\mathrm{R}$ & $\mathrm{R}$ \\
\hline
\end{tabular}

Note. Abbreviation of antifungal disks according to the manufacturers. AMB: amphotericin B (20 ut); CLT: clotrimazole (50 $\mu$ g); FLU: fluconazole $(100 \mu \mathrm{g})$; ECO 10: econazole $(10 \mu \mathrm{g})$; ECO 50: econazole $(50 \mu \mathrm{g})$; ITC: itraconazol $(50 \mu \mathrm{g})$; FC: flucytosine $(1 \mu \mathrm{g})$; KTC: ketoconazole $(10 \mu \mathrm{g})$; GRS: griseofulvin $(10 \mu \mathrm{g})$, MCZ: miconazole $(10 \mu \mathrm{g})$; S: susceptible; I: intermediate; R: resistant. 


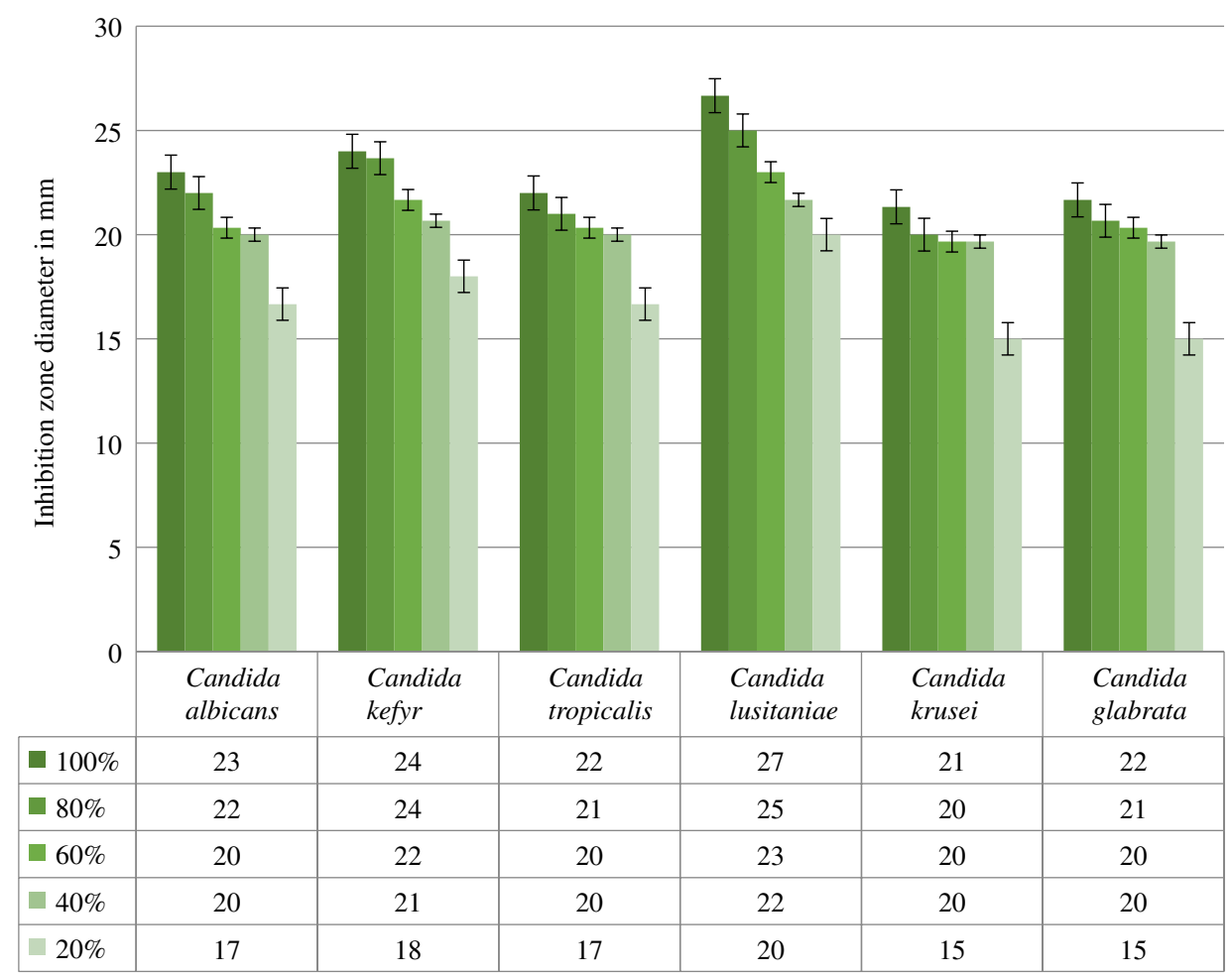

Figure 3. The average results of the antifungal effects of $X$. budapestensis at $24 \mathrm{hr}$

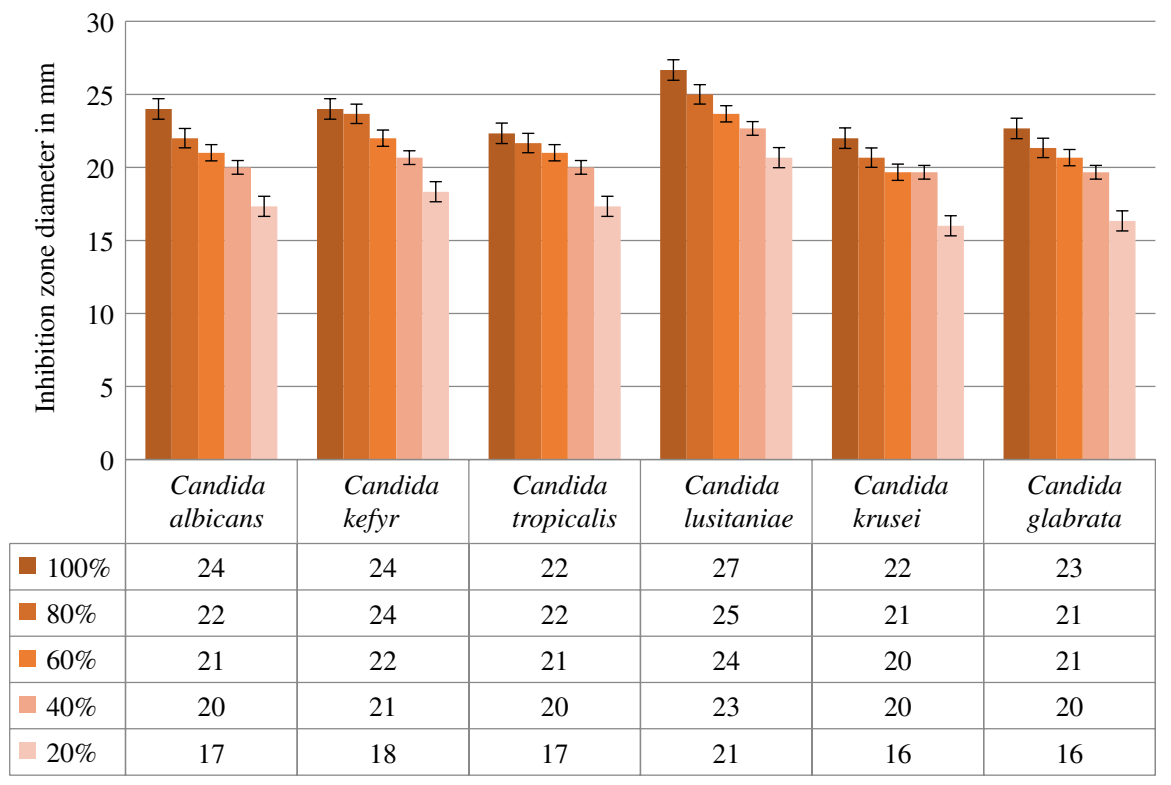

Figure 4. The average results of the antifungal effects of $X$. budapestensis at $48 \mathrm{hr}$

as the zones of inhibition have exceeded $20 \mathrm{~mm}$ in most of the cases. C. lusitaniae appeared to be the most sensitive, whereas $C$. krusei the least sensitive. The sensitivity has been confirmed with $80 \%$ dilutions as well, the zones of inhibition were all larger than $20 \mathrm{~mm}$ with every fungus. In case of $60 \%$ and $40 \%$ dilutions, the Candida species still showed sensitivity though with less intensity.

Based on our previous research, the $20 \%$ dilution was enough to produce the desired effect [15]. In a similar study mentioned at the methodology part, the protein produced by
$X$. cabanillasi called "cabanillasin" had a greater inhibitor effect on C. krusei and C. lusitaniae than on C. albicans and C. glabrata after the 24-hr measurement.

However, the activity of cabanillasin on the tested fungi has decreased after $48 \mathrm{hr}$ in these experiments [17].

Every single tested species showed sensitivity in our case. After $48 \mathrm{hr}$, some of the Candida species showed an increase in the diameter of the zones of inhibition with certain dilutions, but none of the species showed a significant decrease. Similar to the 24-hr results, we have 
The antifungal effect of Xenorhabdus budapestensis

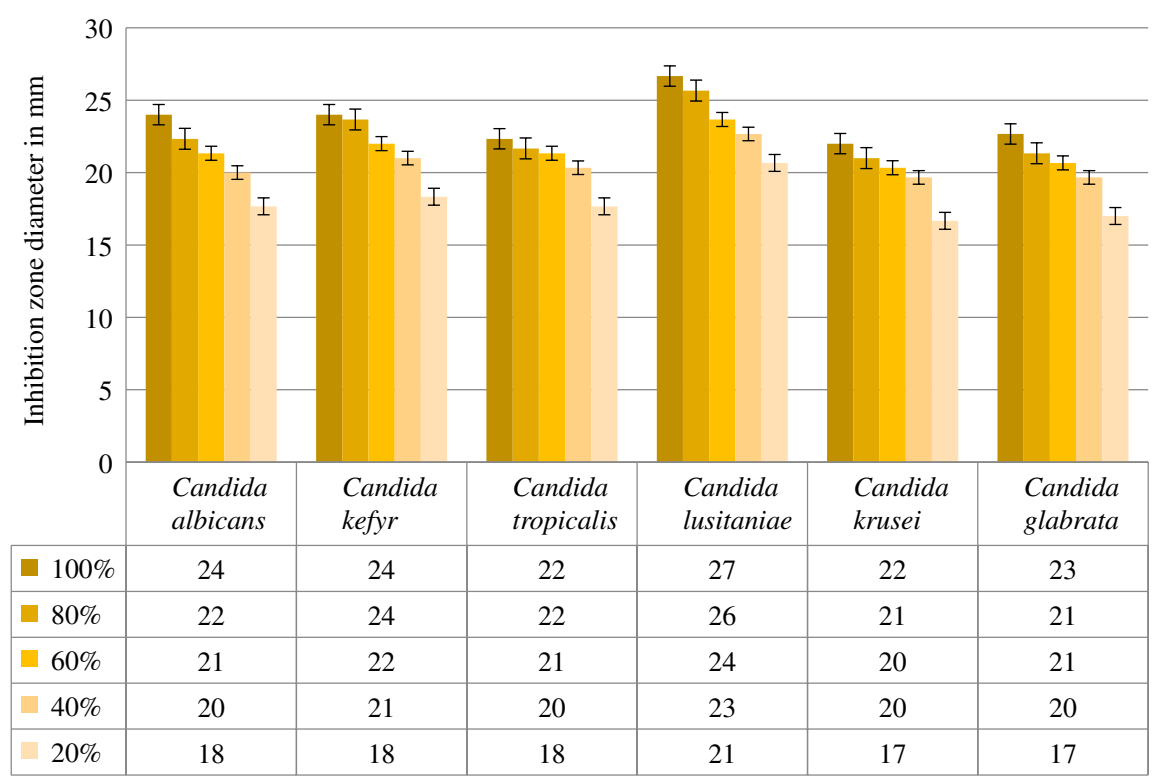

Figure 5. The average results of the antifungal effects of $X$. budapestensis at $96 \mathrm{hr}$

measured zones of inhibition greater than $20 \mathrm{~mm}$ in case of $100 \%, 80 \%, 60 \%$, and $40 \%$ dilutions.

The last measurement of the zones of inhibition was carried out after $96 \mathrm{hr}$. It is observable from the results that there was no decrease in the diameter of the zones of inhibition with any of the Candida species. Therefore, it can be assumed that "fungicide" effect was reached in our experiment. The dry material content was $0.19 \mu \mathrm{g} / \mathrm{ml}$, thus this value can be called the Minimal Fungicidal Concentration (MFC), which was created by the $40 \%$ dilution.

Dry material content was different for each dilution as they had different protein amounts. Solutions with higher concentration had more useful proteins with antimicrobial effect.

There was no relation between the antifungal and XAMP sensitivity of the Candida species. Despite a considerably high resistance against other antifungal compounds, C. lusitaniae showed the highest sensitivity to the proteins in the biopreparation.

It was important to clarify in this study whether different concentrations and protein content have any effect on the intensity and to what degree if there is any. To prove the hypothesis, we used single-factor ANOVA on 5\% significance level.

The result of the test is $p<.001$; therefore, the null hypothesis, which claims that the generated effect depends on the dilution, can be confirmed. This proves that our hypothesis has been confirmed, meaning that significantly greater zones of inhibition have been measured at higher concentration levels and that there is correlation between the antimicrobial effect and the dilution of the biopreparation.

\section{CONCLUSIONS}

Every tested Candida species has shown sensitivity to the proteins synthesised by $X$. budapestensis up to
$40 \%$ dilution. The area of the zones of inhibition did not decrease as time passed during our agar diffusion experiment. We assume that the proteins in the biopreparation have a "fungicide" effect. The greatest sensitivity was shown by $C$. Lusitaniae, whereas C. krusei was the least sensitive. Our results confirmed the previous experiments in which C. albicans showed sensitivity to the antimicrobial protein of $X$. cabanillasi [17].

The frequent and unprofessional usage of antifungal medications significantly decreases the sensitivity of fungi towards these products. Reasons behind the resistance mechanism may include: decreased amount of active agents get into the cell, increased amount of active agents are excreted through the efflux pumps, or the target molecule is modified [24]. There is an increasing need to develop new antifungal medications with new mechanisms and with different active agents.

During our previous studies, we have also confirmed the bactericide effect of the biopreparation of $X$. budapestensis on Gram-positive and Gram-negative bacteria. Gram-positive bacteria were more sensitive, but every tested bacterium showed sensitivity to even the $20 \%$ dilution [15].

\section{ABBREVIATIONS}

$\begin{array}{ll}\text { bicA } & \text { : bicornutin-A gene } \\ \text { CFCM } & : \text { cell-free culture media } \\ \mathrm{HCL} & : \text { hydrogen chloride } \\ \mathrm{MALDI} & : \text { matrix-assisted laser desorption/ionisation } \\ \mathrm{MeOH} & : \text { methyl alcohol } \\ \mathrm{MFC} & : \text { minimal fungicidal concentration } \\ \mathrm{MHF} & : \text { Mueller-Hinton agar fungi } \\ \mathrm{NH}_{4} \mathrm{OH} & : \text { ammonium hydroxid } \\ \mathrm{PF} & : \text { purified fraction } \\ \text { pH } & : \text { pondus hidrogenii }\end{array}$


SD : Sabouraud dextrose agar

XAMP : Xenorhabdus antimicrobial peptide

Acknowledgements: The authors would like to thank associate professor Dr. Katalin Kristóf who provided the identified Candida species to us.

Conflict of Interest/Funding: The authors declare no conflict of interest and no financial support was received for this study.

\section{REFERENCES}

1. Chen LY, Kuo SC, Wu HS, et al. Associated clinical characteristics of patients with candidemia among different Candida species. J Microbiol Immunol Infect. 2013;46(6): 463-8.

2. Pál T. A Medical Microbiology Textbook. Budapest: Medicina Publishing; 2012.

3. Mayer FL, Wilson D, Hube B. Candida albicans pathogenicity mechanism. Virulence 2013;4(2):119-28.

4. Bolotin-Fukuhara M, Fairhead C. Candida glabrata the other yeast pathogen [Editorial]. FEMS Yeast Res. 2016;16(2).

5. Gabaldón T, Carraté L. The birth of a deadly yeast: tracing the evolutionary emergence of virulence traitsin Candida glabrata. FEMS Yeast Res. 2016;16(2).

6. Negri M, Silva S, Henriques M, Oliveira R. Insights into Candida tropicalis nosocomial infections and virulence factors. Eur J Clin Microbiol Infect Dis. 2012;31(7):1399-412.

7. Zhang H, Ran Y, Liu Y, Xiang Y, Zhang R, Dai Y. Clavispora lusitaniae and Chaetomium atrobrunneum as rare agents of cutaneous infection. Mycopathologia 2009;169(5): 373-80.

8. Peyron F, Favel A, Calaf R, Michel-Nquyen A, Bonaly R, Coulon J. Sterol and fatty acid composition of Candida lusitaniae clinical isolates. Antimicrob Agents Chemother. 2002;46(2):531-3.

9. Dufresne SF, Marr KA, Sydnor E, et al. Epidemiology of Candida kefyr in patients with hematologic malignancies. J Clin Microbiol. 2014;52(6):1830-7.

10. Staab JF, Neofytos D, Rhee P, et al. Target enzyme mutations confer differential echinocandin susceptibilities in Candida kefyr. Antimicrob Agents Chemother. 2014;58(9): 5421-7.

11. Kaufmann CA, Marr KA, Thorner AR. Treatment of candidemia and invasive candidiasis in adults [Internet]. [cited 2018 Mar 12]. Available from: https://www.uptodate.com/contents/ treatment-of-candidemia-and-invasive-candidiasis-in-adults
12. Amaral-Lopes S, Moura A. Neonatal fungal sepsis by Candida krusei: a report of three cases and a literature review. Med Mycol Case Rep. 2012;1(1):24-6.

13. Böszörményi E. Entomopathogen bacterium antibiotic activity and symbiotic capacity of gnotobiological analyses [Dissertation]. Budapest: Eötvös University; 2010. 115 p.

14. Böszörményi E, Vozik D, Mária $\mathrm{H}$, et al. Entomopatogén nematoda-szimbionta baktériumok antimikrobiális peptidjeinek hatása antibiotikummal szemben polirezisztens és multirezisztens patogén baktériumokra [Entomopatogenic nematode-symbiotic bacteria antimicrobial peptides effect poly and multidrug resistant patogens bacteria]. Georgicon Agric. 2013;16(1):85-90.

15. Böszörményi E, Barcs I, Domján Gy, et al. Xenorhabdus budapestensis entomopathogenic bacteriacell free conditioned medium and purified peptide fraction effect on some zoonotic bacteria. Orv Hetil. 2015;156(44):1782-6.

16. Furgani G, Böszörményi E, Fodor A, et al. Xenorhabdus antibiotics: a comparative analysis and potential utility for controlling mastitis caused by bacteria. J Appl Microbiol. 2008;104(3):745-58.

17. Houard J, Aumelas A, Noël $T$, et al. Cabanillasin, a new antifungal metabolite, produced by entomopathogenic Xenorhabdus cabanillasi JM26. J Antibiot (Tokyo). 2013;66(10): 617-20.

18. Böszörményi E, Ersek T, Fodor A, et al.. Isolation and activity of Xenorhabdus antimicrobial compounds against the plant pathogens Erwinia amylovora and Phytophthora nicotianae. J Appl Microbiol. 2009;107(3):746-59.

19. Fuchs SW, Grundmann F, Kurz M, Kaiser M, Bode HB. Fabclavines: bioactive peptide-polyketide-polyamino hybrids from Xenorhabdus. Chembiochem. 2014;15(4):512-6.

20. Lengyel K, Lang E, Fodor A, Szállás E, Schumann P, Stackebrandt E. Description of four novel species of Xenorhabdus, family Enterobacteriaceae: Xenorhabdus budapestensis sp. nov., Xenorhabdus ehlersii sp. nov., Xenorhabdus innexi sp. nov., and Xenorhabdus szentirmaii sp. nov. Syst Appl Microbiol. 2005;28(2):115-22.

21. Bonev B, Hooper J, Parisot J. Principles of assessing bacterial susceptibility to antibiotics using the agar diffusion method. J Antimicrob Chemother. 2008;61(6):1295-301.

22. Clinical and Laboratory Standards Institute. Methods for Dilution Antimicrobial Susceptibility Tests for Bacteria that Grow Aerobically; Approved Standard. 9th ed. CLSI document M07-A9. Wayne, PA: Clinical and Laboratory Standards Institute; 2012.

23. Rosco Diagnostica. Susceptibility Testing of Yeasts 2011 [Internet]. Taastrup, Denmark: Rosco Diagnostica; 2011 [cited 2018 Mar 12]. Available from: http://www.rosco.dk/gfx/pdf/yeasts.pdf

24. Maubon D, Garnaud C, Calandra T, Sanglard D, Cornet M. Resistance of Candida spp. to antifungal drugs in the ICU: where are we now? Intensive Care Med. 2014;40(9):1241-55. 